\title{
Forage and tuber yield and nutritional composition of Manihot esculenta Crantz meal with organic fertilization
}

\section{Rendimiento de forraje, tubérculo y composición nutricional de la harina de Manihot esculenta Crantz con fertilización orgánica}

\author{
Elda Yam-Chale ${ }^{1}$, Víctor Díaz-Echeverría ${ }^{1}$, Addy Chavarría-Díaz ${ }^{1}$, Iván Oros-Ortega ${ }^{1}$, Alfonso Chay-Canul ${ }^{2}$, \\ Amelia Cen-Hoy ${ }^{1}$, Fernando Casanova-Lugo ${ }^{1 *}$ \\ ${ }^{1}$ Instituto Tecnológico de la Zona Maya, Tecnológico Nacional de México. Carretera Chetumal-Escárcega km 21.5, CP. 77960, \\ Quintana Roo, México. \\ ${ }^{2}$ División Académica de Ciencias Agropecuarias, Universidad Juárez Autónoma de Tabasco. Carretera Villahermosa-Teapa, km \\ 25, CP. 8628, Villahermosa, Tabasco, México. \\ ${ }^{*}$ Corresponding author: fkzanov@gmail.com
}

Scientific note received: November 5, 2016 accepted: September 23, 2017

\begin{abstract}
The objective was to evaluate the production and nutritional composition of cassava (Manihot esculenta Crantz) meal under different organic fertilization rates. Twenty $10 \times 10 \mathrm{~m}$ plots were planted with cassava and fertilized with $0.0,0.5,1.0$ and $1.5 \mathrm{~kg}$ plant ${ }^{-1}$ of sugarcane filter cake (part of the waste left after processing). The variables measured were fresh and dry forage yield (FFY and DFY), fresh and dry tuber yield (FTY and DTY), meal yield (MY) and their nutritional composition. The results indicate that the organic fertilization significantly increased the FFY, DFY, FTY, DTY and MY compared to the control. Applying $1.5 \mathrm{~kg}$ of organic fertilizer significantly improved crude protein content (CP, 3.37\%). Organic fertilization with $1.5 \mathrm{~kg} \mathrm{plant}^{-1}$ of compost improved forage and tuber yield, and $\mathrm{CP}$ content.
\end{abstract}

Key words: Forage alternative, sugarcane filter cake, compost, nutritional value, local resources

RESUMEN.El objetivo fue evaluar la producción y composición nutricional de la harina de yuca (Manihot esculenta (rantz), bajo diferentes niveles de fertilización orgánica. Se establecieron 20 parcelas de $10 \times 10 \mathrm{~m}$ sembradas con yuca a las que se les aplicó $0.0,0.5,1.0$ y $1.5 \mathrm{~kg} \mathrm{planta}^{-1}$ de composta de residuos de cachaza de caña (Saccharum officinarum L.). Se midió el rendimiento de forraje fresco (RFF) y seco (RFS), rendimiento de tubérculo en fresco (RTF) y seco (RTS), harina (RH) y composición nutricional. La fertilización orgánica incrementó de forma significativa el RFF, RFS, RTF, RTS y RH, con relación al testigo. La aplicación de $1.5 \mathrm{~kg}_{\text {planta }}{ }^{-1}$ de fertilizante orgánico mejoró de forma significativa el contenido de proteína cruda (3.37\%). La fertilización orgánica con $1.5 \mathrm{~kg}_{\text {planta }}{ }^{-1}$ de composta mejora el rendimiento de forraje, tubérculo y contenido de PC.

Palabras clave: Alternativa forrajera, cachaza, composta, valor nutricional, recursos locales

\section{INTRODUCTION}

In the state of Quintana Roo, livestock production is affected by the lack of local inputs for feeding ruminants (Ku et al. 2014). Animal feeding is the fundamental basis of any such production system, because it directly influences its productivity; in this regard, it has been reported that feed is one of the most important factors in the meat production industry because it represents more than $80 \%$ of total production costs (Harun et al. 2017). The preparation of supplements for ruminants is based on the use of cereal grains such as corn and sorghum, which constitute 40 to $60 \%$ of the inputs used, which causes competition between human and animal food (Tesfaye et al. 2014). This 
high demand for grains has increased the use of feed supplements in production systems and consequently limits the development of tropical livestock (Piñeiro-Vázquez et al. 2013); therefore, it is necessary to obtain and manage new inputs for ruminant feeding, which can be easily produced by producers to reduce production costs (CasanovaLugo et al. 2014, Harun et al. 2017).

The cassava (Manihot esculenta Crantz) is a tropical plant that has received little attention as a substitute for cereals in ruminant feed (Harun et al. 2017). The largest area planted in Mexico is in the states of Tabasco and Michoacán, with a national production average of $14 \mathrm{t} \mathrm{ha}^{-1}$ in rain-fed agriculture and $32 \mathrm{t} \mathrm{ha}^{-1}$ under irrigation (Rivera et al. 2012). In this regard, worldwide 196 million $t$ of cassava root are generated every year, of which $28 \%$ are used for animal consumption (Hidalgo and Rodríguez 2015), mainly because the cassava meal efficiently replaces the energy contributed by corn in feed production of animal origin, because the tuber is rich in carbohydrates (Tesfaye et al. 2014, Hidalgo and Rodríguez 2015, Lezcano et al. 2015). Although there is great potential for its use, its cultivation and use in ruminant feeding in southeastern Mexico is non-existent, due to the scarce information on yield and nutritional composition of the meals (Byju et al. 2012, Faezah et al. 2013). Therefore, the aim of this work was to evaluate the effect of different levels of organic fertilization with sugarcane filter cake on forage and tuber yield, production and nutritional composition of cassava meal.

\section{MATERIALS AND METHODS}

\section{Study site}

The study was carried out in the cultivation area of the Instituto Tecnológico de la Zona Maya in Quintana Roo, Mexico, located at the geographic coordinates of $21^{\circ} 51^{\prime} \mathrm{NL}$ and $89^{\circ} 41^{\prime} \mathrm{WL}$, with an Aw1-type subhumid warm climate. The mean annual temperature ranges between 24.5 and 25.8 ${ }^{\circ} \mathrm{C}$; the area is located three meters above sea level, with a flat topography. The predominant soil of the region is Gleysol and the physico-chemical characteristics of the topsoil are shown in Table 1.

Table 1. Physicochemical characteristics of a Gleysol soil in southern Quintana Roo, Mexico.

\begin{tabular}{lc}
\hline Parameters & \\
\hline Ph 7.67 Electrical conductivity (ds/m) & 0.23 \\
Silt (\%) & 45.92 \\
Clay (\%) & 45.90 \\
Sand (\%) & 7.86 \\
Organic matter (\%) & 3.68 \\
Total nitrogen (\%) & 0.18 \\
Phosphorous (ppm) & 43.25 \\
Potassium (ppm) & 1875 \\
Calcium (ppm) & 6100 \\
Magnesium (ppm) & 1611 \\
\hline
\end{tabular}

\section{Experimental plots and design}

The area was prepared with a subsoiler pass, followed by a heavy harrowing pass and two crosswise light harrowing passes. The furrows were made with a cultivator at a distance of $1 \mathrm{~m}$ between lines and later the plots were delimited to assign the treatments and repetitions. The sowing of $M$. esculenta took place at the beginning of June 2014, using vegetative material obtained in the Maya Balam Quintana Roo ejido, from a production plot of $150 \mathrm{~d}$ of establishment. The stems were cut into $40-\mathrm{cm}$ fragments and left to dry for $24 \mathrm{~h}$; they were later planted vertically at a distance of $1 \mathrm{~m}$ between rows and between plants, in $10 \times 10$ m plots, with a density of 100 plants per plot.

Twenty plots were delimited, to which four treatments were applied with 5 repetitions, under a completely randomized design. At 15 and $45 \mathrm{~d}$ after sowing, organic fertilization was provided based on sugarcane filter cake compost (Table 2), which was

Table 2. Chemical composition of sugarcane filter cake from southern Quintana Roo, México.

\begin{tabular}{lc}
\hline Parameters & \\
\hline Ph & 7.08 \\
Organic matter (\%) & 36.90 \\
Organic carbon (\%) & 17.20 \\
Total nitrogen (\%) & 2.64 \\
Phosphorous (\%) & 2.56 \\
Potassium (\%) & 0.59 \\
Calcium (\%) & 5.88 \\
Magnesium (\%) & 0.60 \\
\hline
\end{tabular}


applied manually to the soil surface at $10 \mathrm{~cm}$ from the plant stem, under the treatments of $0.0,0.5$, 1.0 and $1.5 \mathrm{~kg}$ plant ${ }^{-1}$.

\section{Variables evaluated}

Fresh forage and tuber yields (FFY and FTY) were determined at $180 \mathrm{~d}$ after sowing. The samples were bagged and weighed on a $120.0 \mathrm{~kg}$ platform scale. From the FFY and FTY, a random sample of $5.0 \mathrm{~kg}$ of each treatment and repetition was taken to determine the dry forage and tuber yields (DFY and DTY), for which the sample was dried in a forced-air circulation oven at $60{ }^{\circ} \mathrm{C}$ to constant weight. With the FTY per plot, the yield in tons per hectare was estimated.

To prepare the meal, a random sample of 10 $\mathrm{kg}$ of fresh tuber was extracted per treatment and repetition, and then washed and cut into $2 \mathrm{~cm}$ thick slices and dried in a forced-air oven at $60{ }^{\circ} \mathrm{C}$ for $72 \mathrm{~h}$. The material obtained was pulverized in a hammermill with a $3 \mathrm{~mm}$ screen. The dry matter $(\mathrm{DM})$, organic matter (OM), ash ( $\mathrm{Ce}$ ) and crude protein $(C P)$ contents of the meal were determined using AOAC (2012) methods. For neutral detergent fiber (NDF), cellular content (CC) and silica (Si), the method described by Van Soest et al. (1991) was used.

\section{Statistical analysis}

The evaluated variables were subjected to a one-way analysis of variance. When differences were found, Duncan's multiple range test was performed $(p<0.05)$. The analyses were performed with SAS version 9.4 software for Windows (SAS 2013).

\section{RESULTS AND DISCUSSION}

The results show that the FFY was greater with the application of 0.5 and $1.0 \mathrm{~kg} \mathrm{plant}^{-1}$ of filter cake, with yields of 19.84 and $15.82 \mathrm{t} \mathrm{ha}^{-1}$ respectively. The same happened with the DFY ( $p$ $<0.05$ ), showing yields of 4.00 and $3.32 \mathrm{t} \mathrm{ha}^{-1}$ with applications of 0.5 and $1.0 \mathrm{~kg}$ plant $^{-1}$. Regarding tuber production, statistical differences ( $p$ $<0.05$ ) were found with the fertilization of 0.5 and
$1.5 \mathrm{~kg}$ plant $^{-1}$ of filter cake, with the FTY values being 11.99 and $13.02 \mathrm{t} \mathrm{ha}^{-1}$ and the DTY ones 4.09 and $4.20 \mathrm{t} \mathrm{ha}^{-1}$. In the same way, the MY showed significant differences $(p<0.05)$ between the fertilized plots and the control plots, since the 0.5 to $1.5 \mathrm{~kg}$ plant $^{-1}$ filter cake applications showed the best yields (Table 3 ). Several studies show increases in the production and quality of cassava forage with organic fertilization, indicating that organic fertilizers represent a source of nutrients that are quickly assimilated by crops, which improves both the quality and structure of the soil and plant growth (Byju et al. 2012, Cucava et al. 2015). In addition, it has been pointed out that crops grown in soils rich in organic matter are biologically more active and resistant to adverse factors, which increases their production (Gordillo et al. 2011).

The production of cassava forage in fresh $(6.8$ to $\left.19.84 \mathrm{t} \mathrm{ha}^{-1}\right)$ and dry ( 1.5 to $4.0 \mathrm{t} \mathrm{ha}^{-1}$ ) obtained is similar to that reported by Preston et al. (1999), who reported yields of $19.5 \mathrm{t} \mathrm{ha}^{-1}$ in fresh and $3.84 \mathrm{t} \mathrm{ha}^{-1}$ in dry, with organic fertilization of cattle excreta, while the fresh tuber production (4.46 to $13.06 \mathrm{t} \mathrm{ha}^{-1}$ ) is lower than the 7.33-44.16 $\mathrm{t}$ ha ${ }^{-1}$ range reported by Fuenmayor et al. (2012) for different cultivars, and the $48.3 \mathrm{t} \mathrm{ha}^{-1}$ reported by Rivera et al. (2012). The dry tuber production ranged between 1.42 and $4.21 \mathrm{t} \mathrm{ha}^{-1}$, which is lower than the values of 7.62 to $10.37 \mathrm{t} \mathrm{ha}^{-1}$ reported under irrigation (Félix et al. 2014), differences that can be attributed to the age of the cut. However, the volume of production found is within the range of dry matter production reported by Fuenmayor et al. 2012 of $2.19 \mathrm{t} \mathrm{ha}^{-1}$ and $13.39 \mathrm{t} \mathrm{ha}^{-1}$.

The tuber yield in meal ranged between 1.34 and $4.11 \mathrm{t} \mathrm{ha}^{-1}$, which gives an estimated conversion value of $4.75 \mathrm{t}$ of fresh tuber per ton of cassava meal. The above data are within the ranges reported by Cucava et al. (2015), who observed differences in starch content due to the effect of fertilization. However, they are greater than the meal yields reported by Buitrago and Lucket (1998), under rainfed conditions. The differences in the conversion values can be attributed to the harvest time of the crops, as it is known that the shorter the harvest 
Table 3. Forage, tuber and meal yield and nutritional composition of cassava (Manihot esculenta Crantz) meal under different levels of organic fertilization in southern Quintana Roo.

\begin{tabular}{|c|c|c|c|c|c|c|}
\hline \multirow[b]{2}{*}{ Yield (t ha-1) } & \multicolumn{4}{|c|}{ Organic fertilization (kg plant ${ }^{-1}$ ) } & \multirow[b]{2}{*}{ SEM } & \multirow[b]{2}{*}{ Significance } \\
\hline & 0.0 & 0.5 & 1.0 & 1.5 & & \\
\hline Fresh forage & $6.80^{b}$ & $19.84^{a}$ & $15.72^{a}$ & $14.60^{a}$ & 2.35 & $*$ \\
\hline Dry forage & $1.50^{b}$ & $4.00^{a}$ & $3.32^{a}$ & $3.07^{a}$ & 0.46 & * \\
\hline Fresh tuber & $4.45^{b}$ & $11.99^{a}$ & $9.73^{a}$ & $13.02^{a}$ & 2.04 & * \\
\hline Dry tuber & $1.41^{b}$ & $4.09^{a}$ & $3.21^{a}$ & $4.20^{a}$ & 0.70 & * \\
\hline Meal & $1.35^{b}$ & $3.49^{a}$ & $3.21^{a}$ & $4.10^{a}$ & 0.75 & * \\
\hline \multicolumn{7}{|c|}{ Content $(\%)$} \\
\hline Dry matter & $94.02^{a}$ & $94.81^{a}$ & $94.48^{a}$ & $94.58^{a}$ & 0.66 & n.s. \\
\hline Organic matter & $90.61^{a}$ & $91.15^{a}$ & $91.14^{a}$ & $91.13^{a}$ & 0.61 & n.s. \\
\hline Ash & $3.41^{a}$ & $3.46^{a}$ & $3.35^{a}$ & $3.44^{a}$ & 0.09 & n.s. \\
\hline Crude protein & $2.32^{b}$ & $2.14^{b}$ & $1.81^{b}$ & $3.37^{a}$ & 0.29 & $*$ \\
\hline Neutral detergent fiber & $12.84^{a}$ & $15.55^{a}$ & $18.43^{a}$ & $16.99^{a}$ & 1.66 & n.s. \\
\hline Cellular content & $81.18^{a}$ & $79.26^{a}$ & $76.05^{a}$ & $77.58^{a}$ & 1.38 & n.s. \\
\hline Silica & $1.02^{a}$ & $0.32^{a}$ & $0.47^{a}$ & $1.03^{a}$ & 0.21 & n.s. \\
\hline
\end{tabular}

time the smaller the amount of tuber matter, so more tuber is required to obtain a ton of meal.

When the nutritional composition of the obtained cassava meal was analyzed, no differences were found $(p>0.05)$ for the content of DM, OM, $\mathrm{Ce}, \mathrm{NDF}, \mathrm{CC}$ and $\mathrm{Si}$ due to the effect of organic fertilization. However, differences were found ( $p$ $<0.05)$ in the crude protein $(\mathrm{CP})$ content, with the $1.5 \mathrm{~kg}$ plant $^{-1}$ fertilization having the highest content (Table 3). The differences found in the $\mathrm{CP}$ content in cassava meal due to the effect of organic fertilization may be due to the excess of nitrogen required in the crop, which decreases the starch content and increases the protein substances of the roots, which influences the production of cassava meals (Faezah et al. 2013, Tesfaye et al. 2014). It has also been reported that sugarcane filter cake has, on average, $2.29 \%$ nitrogen, which can influence the yield and quality of the tuber (Byju et al. 2012). Although the CP values found are similar to those reported by Ndung'u et al. (2012), they are higher than the values reported by Sahore and Nemlin (2010). The higher CP content found may be due to the lower age of the cut and the use of the tuber and shell, where higher protein content is found.
Regarding the DM content (93.64 to $94.82 \%$ ), values greater than $90 \%$ dry matter were found in cassava meal reported by Cucava et al. (2015). The OM found in cassava flour was 90.61 to $91.15 \%$, values that are higher than those reported by Sahore and Nemlin (2010) in sweet and bitter African cassava varieties. For the mineral matter content, determined by the ash content, values were between 3.35 and $3.44 \%$, which are higher than the values of 2.49 and $2.53 \%$ for sweet and bitter varieties (Sahore and Nemlin 2010), although they can also be due to the harvest time and the processing applied in the preparation of cassava meal. The NDF ranged between 14.43 and $21.02 \%$, values that are lower than those reported for cassava (Sahoré and Nemlin 2010). These differences may be due to the harvest age of the plant, because with the culture age the fiber content increases.

Applying organic fertilization improves fresh and dry forage and tuber yields. The production of dry tuber meal is affected by the amount of fertilization applied. The nutritional composition of cassava tuber meal is not affected by fertilization. The crude protein content is increased with the application of $1.5 . \mathrm{kg} \mathrm{plant}^{-1}$ of sugarcane filter cake. 


\section{ACKNOWLEDGEMENTS}

The authors thank the Instituto Tecnológico

de la Zona Maya for the facilities and supports provided for this research and the Program for Professional Teacher Development for the support given to them.

\section{LITERATURE CITED}

Association of Official Analytical Chemists (AOAC) (2012) Official method of analysis of AOAC international. 19th edition. AOAC international. Gaithersburg, Maryland, USA. pp: 20-44.

Buitrago J, Lucket L (1998) Potencial de la yuca industrial para producción de alimentos balanceados para animales. En: Meex ME, Aldana NH (Ed). Primer encuentro técnico nacional de producción y transformación de yuca. Santa Fe de Bogotá, Colombia. pp:143-156.

Byju G, Nedunchezhiyan M, Ravindran CS, Santhosh-Mithra VS, Ravi V, Naskar SK (2012) Modeling the response of cassava to fertilizers: a site-specific nutrient management approach for greater tuberous root yield. Communications in Soil Science and Plant Analysis 43: 1149-1162.

Casanova-Lugo F, Petit-Aldana J, Solorio-Sánchez FJ, Parsons D, Ramírez-Avilés L (2014) Forage yield and quality of Leucaena leucocephala and Guazuma ulmifolia in mixed and pure fodder banks systems in Yucatan, Mexico. Agroforestry Systems 88: 29-39.

Cucava IB, Eash NS, Zivanovic SDM, Walker FB (2015) Cassava (Manihot escuelenta Crantz) tuber quality as measured by starch and cyanide (HCN) affected by nitrogen, phosphorus, and potassium fertilizer rates. Journal of Agricultural Science 7: 36-49.

Faezah ON, Aishah HS, Kalsom YU (2013) Comparative evaluation of organic and inorganic fertilizers on total phenolic, total flavonoid, antioxidant activity and cyanogenic glycosides in cassava (Manihot esculenta). African Journal of Biotechnology 12: 2414-2421.

Félix EP, Heraldo SA, Jairo GS (2014) Respuesta de dos cultivares de yuca (Manihot esculenta Crantz) (CM 3306-4 y MCOL 2215) a la aplicación de riego en condiciones hídricas diferentes. Acta Agronómica 64: 48-51.

Fuenmayor F, Montilla J, Albarrán J, Pérez M, Vaccarino L, Segobia V (2012) Evaluación y selección de clones de yuca (Manihot esculenta Crantz) del plan nacional de semillas del INIA Venezuela. Revista Científica UDO Agrícola 12: 17-24.

Gordillo F, Peralta E, Chávez V, Contreras A, Campuzano A, Ruiz O (2011) Producción y evaluación del proceso de compostaje a partir de desechos agroindustriales de Saccharum officinarum (caña de azúcar). Revista de Investigación Agropecuaria 37: 140-149.

Harun NLA, Alimon AR, Jahromi MF, Samsudin AA (2017) Effects of feeding goats with Leucaena leucocephala and Manihot esculenta leaves supplemented diets on rumen fermentation profiles, urinary purine derivatives and rumen microbial population, Journal of Applied Animal Research 45: 409-416.

Hidalgo K, Rodríguez B (2015) Alimentación de las aves, cincuenta años de investigaciones en el Instituto de Ciencia Animal. Revista Cubana de Ciencias Agrícolas 49: 197-204.

Ku VJC, Briceño EG, Ruiz A, Mayo R, Ayala AJ, Aguilar CF, Solorio FJ, Ramírez L (2014) Manipulación del metabolismo energético de los rumiantes en los trópicos: opción para mejorar la producción y la calidad de la carne y leche. Revista Cubana de Ciencias Agrícolas 48: 43-53. 
Lezcano P, Vázquez A, Bolaños A, Piloto JL, Martínez M, Rodríguez Y (2015) Ensilado de alimentos alternativos, de origen cubano una alternativa técnica, económica y ambiental para la producción de carne de cerdo. Revista Cubana de Ciencias Agrícolas 49: 65-69.

Ndung'u JN, Wachira FN, Kinyua MG, lelgut DK, Okwaro H, Njau P, Obiero H (2012) Influence of the environment on cassava quality traits in Central Rift Valley of Kenya. American Journal of Plant Science 3: 1504-1512.

Piñeiro-Vázquez AT, Ayala-Burgos A, Chay-Canul AJ, Ku-Vera JC (2013) Dry matter intake and digestibility of rations replacing concentrates with graded levels of Enterolobium cyclocarpum in pelibuey lambs. Tropical Animal Health and Production 45: 577-583.

Preston T, Rodríguez L, Van-Lai N, Chau L (1999) Follaje de yuca (Manihot esculenta Crantz) como fuente de proteína para la producción animal en sistemas agroforestales. En: Sánchez MD, Rosales MM (Ed). Agroforestería para la Producción Animal en Latinoamérica. Roma, Italia. pp.: 478-491.

Rivera HB, Aceves NL, Juárez LJ, Palma LD, González MR, González JV (2012) Zonificación agroecológica y estimación del rendimiento potencial del cultivo de la yuca (Manihot esculenta Crantz) en el estado de Tabasco México. Avances en Investigación Agropecuaria 16: 29-47.

Sahoré DA, Nemlin GJ (2010) Effect of technological treatments on Cassava (Manihot esculenta Crantz) composition. Food and Nutrition Science 1: 19-23.

SAS (2013) Base SAS ${ }^{\circledR} 9.4$ Procedures Guide: Statistical Procedures, Second Edition. Cary, NC: SAS Institute Inc. 550p.

Tesfaye EB, Animut GM, Urge ML, Dessie TA (2014) Cassava root chips and Moringa oleifera leaf meal as alternative feed ingredients in the layer ration. Journal Applied Poultry Research 23: 1-11.

Van Soest PJ, Robertson JB, Lewis BA (1991) Methods for dietary fiber, neutral detergent fiber, and nonstarch polysaccharides in relation to animal nutrition. Journal of Dairy Science 74: 3583-3597. 